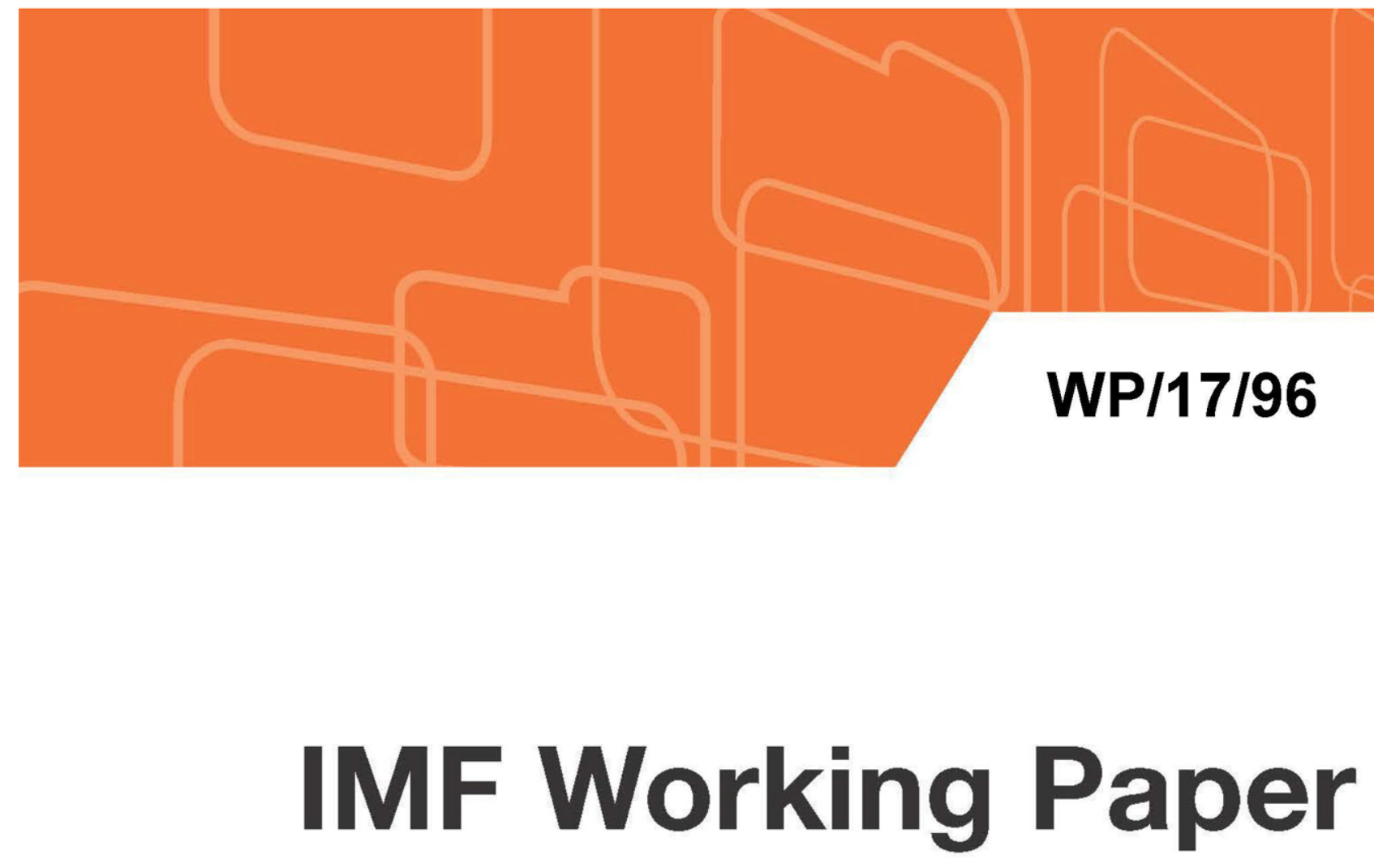

\title{
Understanding the Use of Long-term Finance in Developing Economies
}

By Maria Soledad Martinez Peria and Sergio Schmukler

IMF Working Papers describe research in progress by the author(s) and are published to elicit comments and to encourage debate. The views expressed in IMF Working Papers are those of the author(s) and do not necessarily represent the views of the IMF, its Executive Board, or IMF management. 


\section{WP/17/96}

\section{IMF Working Paper}

\section{Understanding the Use of Long-term Finance in Developing Economies}

By Maria Soledad Martinez Peria and Sergio Schmukler

IMF Working Papers describe research in progress by the author(s) and are published to elicit comments and to encourage debate. The views expressed in IMF Working Papers are those of the author(s) and do not necessarily represent the views of the IMF, its Executive Board, or IMF management.

$$
\text { I N T ER N A T I O N A L M O N E T A R Y F U N D }
$$


IMF Working Paper

Research Department

\title{
Understanding the Use of Long-term Finance in Developing Economies*
} Prepared by Maria Soledad Martinez Peria and Sergio Schmukler

\author{
Authorized for distribution by Giovanni Dell'Ariccia
}

April 2017

\begin{abstract}
IMF Working Papers describe research in progress by the author(s) and are published to elicit comments and to encourage debate. The views expressed in IMF Working Papers are those of the author(s) and do not necessarily represent the views of the IMF, its Executive Board, or IMF management.
\end{abstract}

\begin{abstract}
This short paper reviews recent literature on the use of long-term finance in developing economies (relative to advanced ones) to identify where long-term financing occurs, and what role different financial intermediaries and markets play in extending this type of financing. Although banks are the most important providers of credit, they do not seem to offer long-term financing. Capital markets have grown since the 1990s and can provide financing at fairly long terms. But few firms use these markets. Only some institutional investors provide funding at long-term maturities. Governments might help to expand long-term financing, although with limited policy tools.
\end{abstract}

JEL Classification Numbers: F65, G00, G01, G10, G11, G15, G18, G20, G21, G23, G28

Keywords: banks, bond markets, firm financing, financial crises, financial intermediaries, institutional investors, issuance maturity, long-term debt, short-term debt

Author's E-Mail Address: mmartinezperia@imf.org; sschmukler@worldbank.org.

\footnotetext{
* The paper summarizes the main findings from Chapters 1 and 4 of the World Bank Global Financial Development Report (GFDR) 2015 and was prepared as a chapter of a forthcoming CEPR book entitled "Finance and Investment: The European Case”. Facundo Abraham provided excellent research assistance. We received very helpful comments from participants at presentations of the GFDR held at the Central Bank of Argentina (Buenos Aires), Central Bank of Chile (Santiago), CSEF-University of Naples Federico II (Naples), Università Bocconi (Milan), and the World Bank (Washington, DC). For financial support, we are grateful to the Assonime/CEPR Research Programme on Restarting European Long-Term Investment Finance (RELTIF) and to the World Bank Knowledge for Change Program. The views expressed in this paper are those of the authors and do not necessarily represent those of the IMF or the World Bank, these institutions' Executive Boards, or their management.
} 


\section{Table of Contents}

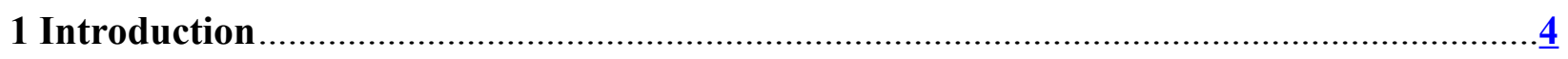

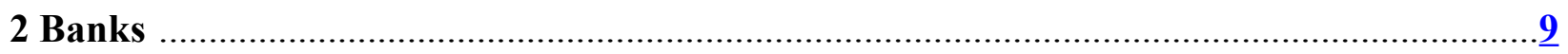

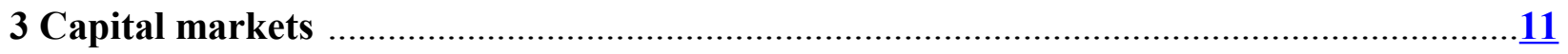

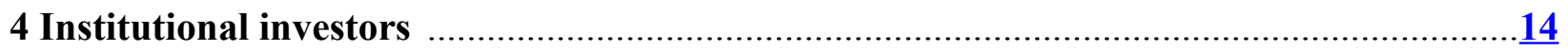

4.1 Portfolio Maturity of Domestic Institutional Investors: The Case of Chile …………….....15

4.2 International Evidence on Mutual Funds .....................................................................

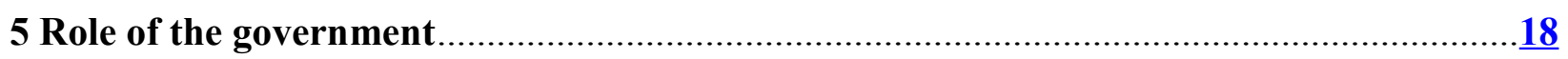

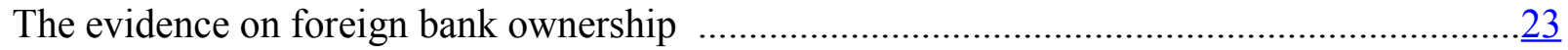

The evidence on government bank ownership ………………............................................

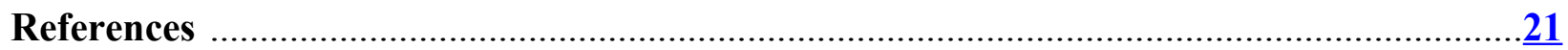

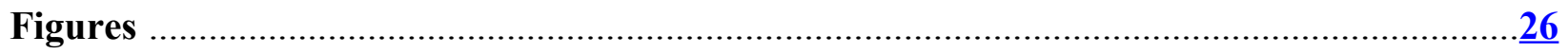

Figure 1 Average Share of Bank Loans in Advanced and Developing Economis by Maturity,

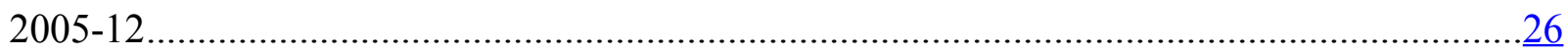

Figure 2 Capital Market Size and Composition by Country Income Group, 2000-11 ..............26 Figure 3 Institutional Investor Assets by Country Income Group, 2000-11 ............................27 Figure 4 Average Maturity Structures of Chilean Institutional Investors, 2002-2008...............27 Figure 5 Comparison of Average Maturity of Corporate Bonds Held by U.S. and U.K. Mutual Funds and Domestic Mutual Funds, 2013 ..............................................................................28 


\section{Introduction}

Lack of adequate long-term financing has become an important and challenging issue in many developing economies, particularly since the global financial crisis of 2008-09. Having access to long-term funds is critical because it can allow governments and firms to finance large long-term investments as well as to reduce rollover risks and the potential for runs. Moreover, there is vast evidence that short-termism has contributed to several well-known financial crises in both developing and high-income economies (Eichengreen and Hausmann, 1999; Rodrik and Velasco, 2000; Tirole, 2003; Borensztein et al., 2005; Jeanne, 2009; Brunnermeier, 2009; Raddatz, 2010; Beltratti and Stulz, 2012; Broner, Lorenzoni, and Schmukler, 2013).

As a consequence, several reports and studies have emphasized the need for long-term finance. The World Bank Global Financial Development Report 2015 examines evidence of the use and economic impact of long term-finance with the goal of identifying those policies that help to promote it and those that do not (World Bank, 2015). Likewise, the OECD issued a set of principles to facilitate and promote long-term investment by institutional investors (OECD, 2013a). Also, the Financial Stability Board (FSB) highlights the impact that recent regulatory reforms (including, Basel III and derivatives markets reforms, among others) could have on the provision of long-term finance (FSB, 2013). Furthermore, the Restarting European Long Term Investment Finance Program (RELTIF) has argued that SMEs in Europe have a shortage of longterm finance and puts forward key policy questions to address this issue (Giovannini et al., 2015). ${ }^{1}$

\footnotetext{
${ }^{1}$ In this paper we do not adopt any particular definition of long-term finance, as the concept is not precisely defined in the literature. One common definition, used in the national accounts, considers long-term finance to be any source of funding with maturity exceeding one year. In contrast, the Group of 20 uses a maturity of five years (G-20, 2013). Longterm finance includes many instruments and intermediaries such as bank loans and bond markets as well as equity (public or private), since it is a financial instrument with no final repayment date.
} 
But long-term financing is not necessarily desirable in all situations. In fact, this type of financing can be best understood as arising from a trade-off between creditors and debtors in the allocation of risk. Long-term finance shifts risk to the providers of funds because they have to bear the fluctuations in the probability of default and the loss in the event of default, along with other changing conditions in financial markets, such as interest rate volatility. In contrast, short-term finance shifts risk to the users of credit because it forces them to refinance their debt repeatedly. Therefore, long-term debt might be optimal only in some situations.

Users of credit (households, firms, or the government) would prefer long-term debt if they aim to reduce rollover and interest rate risks. The former is the risk that credit lines are cancelled or modified at short notice, while the latter is the risk that interest rates and loan terms are changed at short notice. Both risks generate economic costs because the mismatch between short-term financing and long-term investment projects can force their premature liquidation, which can be socially inefficient and generate losses for the economy as a whole. In some cases, this mismatch can discourage profitable investments with a longer time horizon from being undertaken in the first place.

Households might prefer long-term finance because it can raise their welfare by allowing them to smooth their consumption over time and by facilitating lumpy investments such as housing. Moreover, long-term funds might allow households to insure against the challenges of retirement, education needs, health shocks, premature death, or longevity risks. Long-term financing can be important for firms too, because it enables them to undertake lumpy and large investments that might be critical for their growth. In the absence of long-term financing, firms might have to rely on short-term debt, and their inability to roll over short-term debt might cause 
a firm to exit or to curtail profitable long-term investments with consequences for their growth potential (Almeida et al., 2011).

But in some other instances users might prefer short-term finance. Firms tend to match the maturity of their assets and liabilities; hence the faster the returns to investment are realized, the shorter the optimal payment structure will be (Hart and Moore, 1995). Thus, long-term loans are usually used to acquire fixed assets, equipment, and the like while short-term loans, on the other hand, are preferred for working capital, such as payroll, inventory, and seasonal imbalances. In addition, a firm or a household that anticipates improvements in its financial situation might prefer short-term financing rather than being locked in a longer contract that might not reflect the medium or long-term prospects. For example, firms with high credit ratings might prefer short-term debt because it allows them to refinance the terms of their debt when good news arrives (Diamond, 1991). Households and firms might also prefer short-term contracts if the payoffs from available investment projects have a similarly short-term horizon or if the cost of long-term finance is too high.

The benefits of long-term finance can accrue not only to borrowers but also to providers of funds (savers in the economy) and financial intermediaries (banks and institutional investors). Lenders might be willing to engage in long-term financial contracts because returns are higher than short-term contracts and because the maturity of these contracts might match their long-term saving needs. For the economy as a whole, long-term finance might contribute to higher growth and lower macroeconomic volatility (Aghion, Howitt, and Mayer, 2005). In addition, long-term finance is critical for infrastructure projects, which by nature take many years to complete and require lumpy investments. 
Short-term debt might prove useful in other situations. Lenders might at times prefer to provide short-term financing to guard against moral hazard and agency problems in lending. Financing contracts with a short maturity improve the lender's ability to monitor borrowers through the implicit threat of restricted access to credit in the future, if debtors are not taking actions that maximize the repayment probability of the financing obtained (Rajan, 1992; Rey and Stiglitz, 1993; Diamond and Rajan, 2001). Equity might mitigate some of this monitoring issues that lead to short-term financing, because shareholders and, in particular, private equity investors can control the management of an investee firm more directly than a financial institution can.

Even in situations when users and providers of finance would ideally prefer long-term finance, market failures and policy distortions could lead to lower-than-desired equilibrium longterm finance for the different parties involved. First, because extending long-term finance implies large risks for providers, information asymmetries could prevent creditors from knowing the true repayment capacity and willingness to pay of borrowers, making creditors reluctant to agree to the amount of long-term finance requested (Stiglitz and Weiss, 1981). Second, coordination problems can shorten debt maturity. When the seniority of claims is not well enforced and lenders cannot coordinate their actions, they will protect themselves against dilution by simultaneously shortening the maturity of their claims (Bolton and Jeanne, 2009; Brunnermeier and Oehmke, 2013). This situation may trigger a "maturity rat race" in which lenders shorten the maturity of contracts to protect their claims and shorten the average maturity of debt contracts available in equilibrium. Third, incentive problems of the financial intermediaries may lead to an undersupply of long-term financing, even in economies with a well-developed financial sector. Short-term investment can be driven, not by supply side factors or a lack of availability of long-term instruments, but rather by the practice of evaluating fund managers against short-term performance targets (Bebchuk and 
Stole, 1993; Campbell and Viceira, 2002; Opazo, Raddatz, and Schmukler, 2015). A similar problem has emerged in the corporate sector, where companies are evaluated on the short-term by shareholders, limiting their ability to pursue long-term goals (Davies et al., 2014; The Economist, 2015a, 2015b).

This short paper reviews the recent literature and discusses the degree to which the use of long-term finance is prevalent in developing economies (relative to advanced ones) by focusing on the role of the most important providers of long-term finance: banks, capital markets, and institutional investors. The paper argues that the use of long-term finance in developing economies is more limited than in advanced ones. Banks, the most important source of long-term financing, lend at significantly shorter maturities in developing economies relative to advanced ones. Moreover, capital markets in developing economies are less developed and are accessible only to a small proportion of total firms. Domestic institutional investors not only have a small participation in developing economies, but also the incentives they face can lead them to invest short-term. However, access to international mutual funds can help developing economies to obtain not only more funds, but also more long-term financing, as these investors hold longer maturities compared to domestic mutual funds. The paper ends with a set of policy recommendations that might help governments to address some of the shortcomings in the provision of long-term finance in developing economies.

The rest of the paper is organized as follows. Section 2 summarizes the evidence on banks, focusing on domestic credit. Sector 3 discusses the evidence of issuance activity in capital markets. Section 4 presents some evidence on institutional investors, first using the case of Chile to illustrate the asset maturity structure of insurance companies, mutual funds, and pension funds, and second comparing domestic and foreign mutual funds investments in developing economies. Section 5 
discusses the possible role of the government in extending the maturity structure in different parts of the financial sector.

\section{Banks}

Banks are the main source of finance for firms and households, and thus are essential to understand the debt maturity structure across economies. By pooling savings and transforming short-term deposits into long-term loans, banks take on liquidity risks (arising from the maturity mismatch between their assets and liabilities) and can provide financing for illiquid long-term projects (Diamond and Dybvig 1983).

Bank-level data from Bankscope across economies suggest that the maturity of bank loans in advanced economies is significantly longer than in developing ones. For example, whereas close to a third of bank loans in high-income economies have a maturity that exceeds five years, for developing economies the share of loans with maturity larger than 5 years averages 18 percent (Figure 1). In contrast, while half of bank loans are short-term (less than 1 year) in developing economies, the share of short-term loans in advanced economies averages 40 percent. There are smaller differences between advanced and developing economies in the share of loans with maturity between 2 and 5 years: for advanced economies this share averages 28 percent and it averages 32 percent for developing economies.

Syndicated loans, typically provided by large international banks to large firms, show a different picture. For these, the maturity of loans is lower in advanced economies compared to developing economies. The median and average maturity of syndicated loans in high income economies is close to six years, while in middle and low-income economies these statistics are closer to seven years. However, these disparities are driven by differences in loan types as in 
developing economies most syndicated loans are for project finance or infrastructure loans, which tend to have longer maturities, while in advanced economies the majority of syndicated loans are general purpose corporate loans with shorter maturities (Cortina-Lorente, Didier, and Schmukler, 2017). Moreover, differences in the types of firms obtaining financing in different economies also explain these patterns (Cortina-Lorente, Didier, and Schmukler, 2016).

Specific country characteristics seem important to understand bank loan maturity. Evidence shows that macroeconomic factors such as low inflation (Demirgüç-Kunt and Maksimovic, 1999; Kpodar and Gbenyo, 2010; Tasić and Valev, 2008, 2010), country risk (Qian and Strahan, 2007; Bae and Goyal, 2009), and strong institutions (Fan, Titman, and Twite, 2012) help to lengthen bank maturity. Moreover, other country characteristics, such as the degree of development of the financial sector, the ability to effectively enforce financial contracts, the collateral framework, and the credit information environment, among others, have been found to be positively correlated with bank loan maturity (Djankov, McLiesh, and Shleifer, 2007; Qian and Strahan, 2007; Tasić and Valev, 2008, 2010; Bae and Goyal, 2009; Love, Martinez Pería, and Singh, 2016).

Moreover, bank characteristics also affect the maturity of bank loan portfolios (Tasic and Valey, 2010; Chernykh and Theodossiou, 2011; Constant and Ngomsi 2012). Larger banks are expected to exhibit higher shares of long-term to total loans relative to other banks because they tend to be more diversified, have greater access to funding, and have more resources to develop credit risk management and evaluation systems to monitor their loans. Likewise, better capitalized banks are more likely to issue long-term loans because they are more capable of dealing with the associated risks and absorbing potential losses. Bank ownership also seems to influence bank loan maturity. Contrary to the conventional wisdom, a wider presence of state-owned banks reduces 
maturity whereas foreign banks are more likely to be involved in long-term lending. Furthermore, the type of funding is important, as banks with a higher share of long-term liabilities exhibit higher shares of long-term loans.

Bank regulations can impact long-term finance as well. Policies such as deposit insurance can lower the risk of bank runs and, thus, reduce banks' need to hedge this risk by issuing shorterterm loans (Fan, Titman, and Twite, 2012). Furthermore, regulations that affect bank size, capitalization, and funding are likely to affect long-term finance, as these bank characteristics are correlated with the maturity structure of bank loans (G20, 2013). For example, the proposed reforms on capital requirements and new minimum liquidity set in Basel III can indirectly affect long-term finance by increasing the amount of regulatory capital for such transactions, dampening the scale of maturity transformation risks. The impact on developing economies could be more severe because these economies have less developed markets and fewer nonbank financial intermediaries and, therefore, would suffer more if banks cut back on long-term finance as a result of these regulatory changes.

\section{Capital markets}

Capital markets, mostly comprising bond and stock markets, are another potential source of long-term financing for firms. Bond markets tend to be large and can provide funding at fairly long terms relative to banks. Equity can per se be considered long term as companies can determine when and how much dividends to return to shareholders, thus assuming no short-term risk.

Capital markets are significantly larger in advanced economies than in developing ones. For example, from 2000 to 2011, the total capitalization of these markets (including public debt) averaged approximately 203 percent of GDP in high-income economies, almost 98 percent in 
upper-middle-income economies, and 62 percent in lower income economies (Figure 2). Median values are lower (in particular among high-income economies), showing the influence of outliers within each income category, but the main pattern remains the same and capital market capitalization is positively correlated with income.

In advanced economies, stock markets tend to dominate, followed by private bond markets. On average, the two markets account for 157 percent of GDP: stock market capitalization is almost 81 percent of GDP and private bond market capitalization accounts for close to 76 percent. In contrast, in developing economies, stock markets are also important, but public instead of private debt markets come second in place. On average, in upper-middle-income economies stock market capitalization is almost 43 percent of GDP and public bond market capitalization accounts for 38 percent. Private bond markets account for 17 percent of market capitalization on average. In the two lower-income groups, private debt markets are very small at 3 percent of GDP.

The maturity of corporate bond issues is not clearly tied to country income. The average maturity of corporate bond issues in upper-middle-income economies is the highest ( 7.6 years) followed by high-income economies (6.7 years) and lower-middle- and low-income economies (6.3 years). One reason driving lower maturities for high-income economies is that a larger percentage of bond issues are by financial firms, and these issues tend to have a shorter maturity (Cortina-Lorente, Didier, and Schmukler, 2016, 2017).

But only a few large firms use these financial markets, and only the largest and oldest ones issue at the long end of the maturity spectrum (Claessens and Schmukler, 2007). For the set of firms that do use long-term markets, those in developing economies do not issue at shorter maturities than those in high-income economies. However, in developing economies firms tend to be smaller in size so, as a result, a smaller proportion of firms are able to access equity, bond, and 
syndicated loan markets. This problem is exacerbated by an overreliance of developing economies on international capital markets to raise funds at the long end of the maturity spectrum. Firms that issue in international markets have to overcome an apparently even larger minimum size requirement than those firms that use domestic markets to obtain longer-term funds, and might also get exposed to currency risk (Gozzi et al., 2015).

As a result, developing-economies firms would benefit from further development of their domestic capital markets. More developed domestic markets would reduce the reliance on international markets for those firms from developing economies that are able to issue debt and would imply a more inclusive, broader use of long-term finance in these economies. Domestic markets might need to complement, and not substitute, international markets as the latter also have their benefits. International markets allow firms to access a wider and more diverse set of investors. This could be a way to extend the maturity profile of corporate debt for firms from developing economies. Also, foreign investors might be willing to take on more risk when investing in developing economies, especially when the returns of investing in high-income economies are compressed.

To foster the development of the domestic capital markets, a main challenge is to broaden access to long-term capital markets beyond a very select group of large firms. For instance, reducing the transaction costs associated with the issuance process could enlarge the number of firms that are able to access capital markets, with positive spillover effects on the secondary markets and the overall economic growth of countries. Another way to allow smaller and lowerrated firms to access capital markets would be to develop innovative instruments, such as minibonds, and through loan securitization (Borensztein et al., 2008; Giovannini et al., 2015). 
A complementary challenge is to increase the investor base and expand the scope of investors' portfolios. In principle, countries with small market sizes and investor bases would gain from promoting foreign investor participation in domestic markets or achieving greater access to foreign markets. For example, in high-income economies with the most developed capital markets, relatively smaller firms are able to issue capital (Didier, Levine, and Schmukler, 2015). This suggests that, as financial markets develop, the extensive margin of firms using these markets might expand, so that smaller firms could participate more in these markets. In addition, the introduction of new financial instruments for investors such as explicit seniority or GDP-linked sovereign debt instruments could also help to lengthen debt maturity (Borensztein et al., 2005).

\section{Institutional investors}

Over the past two decades, many countries have tried to foster long-term finance through the promotion of nonbank domestic institutional investors. The belief is that these investors have long investment horizons, which allow them to take advantage of long-term risk and illiquidity premiums to generate higher returns on their assets. Moreover, they are expected to behave in a patient, countercyclical manner, making the most of cyclically low valuations to seek attractive long-run investment opportunities and, thus, help to deepen long-term financial markets. This view has been expressed in several studies and articles (Caprio and Demirgüç-Kunt 1998; Davis 1998; Davis and Steil 2001; Corbo and Schmidt-Hebbel 2003; Impavido, Musalem, and Tressel 2003; BIS 2007; Borensztein et al. 2008; Impavido, Lasagabaster, and Garcia-Huitron 2010; Della Croce, Stewart, and Yermo 2011; OECD 2013b,c, 2014; The Economist 2013, 2014; Financial Times 2015). 
During 2000-2011, the participation of institutional investors in developing economies was still relatively small (Figure 3). The cumulative assets of institutional investors - pension funds, mutual funds, and insurance companies - averaged 99 percent of GDP in high-income economies, with broadly similar shares for the three sets of institutional investors. In contrast, the assets of these institutions averaged only 25 percent of GDP in upper-middle-income economies, where pension funds predominated. In lower-income economies, the share of institutional investor's assets to GDP was even lower, averaging close to 12 percent, with pension funds accounting for half of the total.

Little evidence exists on whether these investors actually invest in long-term securities and how they structure their asset holdings. Different types of institutions with different objectives are likely to provide funding for financial markets in distinct ways. For example, some institutional investors might need to match the maturity of their assets to their liabilities, while others might have only fiduciary responsibilities for managing their assets, without specific directives to invest short or long term. Also, the way regulations are set up can affect the incentives that asset managers have to avoid excessive risk and, thus, the maturity profile of the portfolios they choose.

The remaining of this section explores the behavior of institutional investors in developing economies, by (a) analyzing the case of insurance companies, mutual funds, and pension funds in Chile (drawing on Opazo, Raddatz, and Schmukler, 2015) and (b) comparing the behavior of domestic and foreign mutual funds when investing in developing and advanced economies.

\subsection{Portfolio Maturity of Domestic Institutional Investors: The Case of Chile}


Analyzing the differences in the maturity structure of nonbank institutional investors in Chile and the factors that lie behind them is relevant because it challenges the expectation that institutional investors across the board would always help to lengthen the maturity structure. This situation is not Chile-specific, as the kind of regulations in place in this country have been also adopted by other developing economies in Latin America and Central Europe.

The evidence shows that Chilean asset-management institutions (mutual and pension funds) hold a large amount of short-term instruments and overall invest shorter term relative to insurance companies (Figure 4). Both mutual funds and pension funds invest more than half of their portfolios in maturities of three years or less, whereas insurance companies invest a little more than one-third of their portfolios in these shorter-term maturities. As a result, the average maturity for insurance companies (9.77 years) is more than double that of mutual funds (3.97 years) and pension funds (4.36 years).

The observed short-termism of pension funds is not constrained by the supply side of instruments as Chilean asset managers choose short-term instruments even when assets for longterm investments are widely available and when other investors hold them. In turn, the incentives faced by these investors seem to drive the difference in debt maturity structures between pension and insurance funds. In Chile, managers of open-end funds, such as pension funds, are monitored in the short-run by investors, the regulator, and the asset-management companies. This short-run monitoring combined with the risk profile of the available instruments generates incentives for managers to be averse to investments that are profitable at long horizons (such as longer-term bonds) but that can have poor short-term performance. In contrast, insurance companies are not open-end asset managers, receive assets that cannot be withdrawn in the short run, and have longterm liabilities because investors acquire a defined benefit plan when purchasing a policy. Thus, 
insurance companies are not subject to the same kind of short-run monitoring and hence tend to hold long-term assets in their portfolios.

Overall, Chile's experience shows that the development of large and sophisticated institutional investors with deep pockets does not guarantee an increased demand for long-term assets. Merely establishing asset management institutions and assuming that managers will invest long term does not appear to yield the expected outcome, especially if they would be subject to a similar type of market and regulatory short-term monitoring as that in Chile.

\subsection{International Evidence on Mutual Funds}

In recent years, the importance of international mutual funds has been growing. This growth is attributable mainly to investors in advanced economies who have increasingly sought to diversify their portfolios by investing in other economies including developing ones, often through dedicated emerging markets funds or through increased emerging market participation by globally active funds (Gelos 2011).

U.S. and U.K. mutual funds invest longer term when investing in developing economies than domestic ones when investing in the same domestic debt instruments. Namely, these funds tend to invest longer term in corporate bonds than the average maturities of the domestic funds in the economies in which they invest (Figure 5). Hence, mutual funds from international financial centers seem to play some role in extending the maturity structure of corporate bonds in developing economies.

One potential reason for this behavior is that international mutual funds might be willing to take the higher risk of investing more long-term given their larger size and their ability to diversify this risk by investing in different economies around the world. In addition, domestic 
funds in developing economies might be subject to larger outflows related to performance, and so they might have incentives to hold a higher proportion of short-term instruments.

\section{Role of the government}

The role of the government in the provision of long-term finance by financial sector participants is not obvious. It would depend on what the obstacles are and whether the government can pull any policy levers. To the extent that long-term finance is limited by market failures and economic and institutional weaknesses, government policies could play a role.

For example, measures that promote information sharing mechanisms, such as the creation of credit bureaus, could be useful (Tasić and Valev, 2008; Martinez Peria and Singh, 2014). Likewise, high political risk or an unstable macroeconomic environment undermines the ability of economic agents to predict risks and returns and, hence, short-term finance will be the most prevalent form of external financing (Caprio and Demirgüç-Kunt 1998). At the same time, prospective borrowers will be reluctant to invest in their future, and the demand for long-term finance will be low. Thus, reducing aggregate uncertainty can help. One example is the negative effect of inflation on long-term debt (Demirgüç-Kunt and Maksimovic, 1999; Jeanne and Guscina, 2006; Kpodar and Gbenyo, 2010).

A strong legal and institutional framework can also help with the supply of long-term debt. When a country's contracting institutions have only very weak protections for creditors, lenders tend to rely on short-term lending agreements, which make it easier for them to discipline borrowers through the threat of withholding future financing in case of non repayment (Qian and Strahan, 2007; Warnock and Warnock, 2008; Fan, Titman, and Twite 2012). A sound legal and regulatory framework might include a strong capability to enforce contracts, adequate collateral 
framework, provisions that ensure the existence of competitive and contestable markets for financing, and appropriate corporate governance and accounting standards (Bae and Goyal, 2009; De Haas, Ferreira, and Taci, 2010; Fan, Titman, and Twite 2012; Love, Martinez Peria, and Singh, 2016).

Considering the relatively small size of domestic capital markets in developing economies, governments in developing economies could try to facilitate the development of efficient capital markets. Some interventions, such as stock market liberalization, enforcement of insider trading laws, the introduction of electronic trading systems, privatization programs, and institutional reforms, tend to be associated with significant increases in domestic stock market capitalization and trading volumes. However, how that trickles down to the overall economy in terms of longterm funds is still not well known.

As the Chilean evidence shows, governments can also promote long-term financing through policies that set the right incentives and remove unnecessary restrictions that discourage institutional investors to invest long-term. To reduce the focus on short-term performance, governments need to ensure that compensation and benchmarking practices followed by institutional investors have a long-run horizon (Rudolph et al., 2010; Berstein, Fuentes, and Villatoro 2013; Stewart, 2014). But this is easier said than done.

The evidence on international mutual funds indicates that promoting the entry of foreign investors might be an avenue for extending corporate debt maturities in developing economies. However, promoting foreign institutional investors entails an important trade-off because economies become more susceptible to foreign shocks, as it became clear during the financial crisis of 2008-09. Some of these institutional investors might exhibit the same type of procyclical 
risk taking that banks are known for and may not conform to the textbook picture of long-term investors, but instead have much in common with banks in amplifying shocks (Shin, 2013).

Public-private partnerships (PPP) might be an example of how public institutions can support the provision of long-term finance without distorting market incentives. Long-term finance through PPPs is an attractive alternative to direct public financing because it reduces crowding out of private investment, reduces cyclicality of public spending by contractually distributing costs over a long time horizon, and aligns institutional incentives in large investment projects more closely with those of the private sector. In addition, governments can generate incentives to facilitate long-term investments by alternative institutional investors, such as sovereign wealth funds (SWFs). Because of their long time horizon and the lack of redemption risk, SWFs are better able to invest in illiquid assets with longer maturities (Gelb et al., 2014). Nonetheless, while their long investment horizon makes SWFs natural providers of long-term finance, they are not immune to political capture and incentive misalignment. Government-owned banks can be used as tools to promote long-term financing. However, public sector interventions should be limited only to cases where a market failure is apparent and where no private sector solution is feasible. To ensure that the involvement of government-owned financial institutions serves as a remedy rather than a source of market distortions, the purpose, scope, and time horizon of the involvement need to be clearly defined (Scott, 2007; Rudolph, 2009; de la Torre, Gozzi, and Schmukler, 2017).

One of the major obstacles to study the role of financial intermediaries in the provision of long-term finance is the shortage of international and domestic data on portfolios and institutional ownership of debt securities and bank loans. Although most national authorities collect this information, a joint effort is needed to consolidate it and make it comparable across countries. Such efforts should highlight further steps to foster long-term financing via financial institutions. 


\section{References}

Aghion, Philippe, Peter Howitt, and David Mayer. 2005. "The Effect of Financial Development on Convergence.” Quarterly Journal of Economics 120 (1): 173-222.

Almeida, Heitor, Murillo Campello, Bruno Laranjeira, and Scott Weisbenner. 2011. "Corporate Debt Maturity and the Real Effect of the 2007 Credit Crisis." Critical Finance Review 1: 3-58.

Bae, Kee-Hong, and Vidhan K. Goyal. 2009. "Creditor Rights, Enforcement, and Bank Loans." Journal of Finance 64 (2): 823-60.

Bebchuk, Lucian Arye and Lars A. Stole. 1993. "Do Short-term Objectives Lead to Under- or Overinvestment in Long-term Projects?” Journal of Finance 48(2), 719-729.

Beltratti, Andrea, and René Stulz. 2012. "The Credit Crisis around the Globe: Why Did Some Banks Perform Better?” Journal of Financial Economics 105(1): 1-17.

Berstein, Solange, Olga Fuentes, and Félix Villatoro. 2013. "Default Investment Strategies in a Defined Contribution Pension System: A Pension Risk Model Application for the Chilean Case." Journal of Pension Economics and Finance, 12(04), 379-414.

BIS (Bank for International Settlements). 2007. "Institutional Investors, Global Savings, and Asset Allocation.” CGFS Paper 27, BIS, Basel.

Bolton, Patrick, and Olivier Jeanne. 2009. "Structuring and Restructuring Sovereign Debt: The Role of Seniority." Review of Economic Studies 76 (3): 879-902.

Borensztein, Eduardo, Marcos Chamon, Olivier Jeanne, Paolo Mauro, and Jeromin Zettelmeyer. 2005. "Sovereign Debt Structure for Crisis Prevention." IMF Occasional Paper 237. International Monetary Fund.

Borensztein, Eduardo, Kevin Cowan, Barry Eichengreen, and Ugo Panizza. 2008. "Bond Markets in Latin America: On the Verge of a Big Bang?” Journal of Economic Literature 47 (4): 1146-49.

Broner, Fernando, Guido Lorenzoni, and Sergio Schmukler. 2013. "Why Do Emerging Economies Borrow Short Term?" Journal of the European Economic Association 11 (1): 67-100.

Brunnermeier, Markus. 2009. “Deciphering the Liquidity and Credit Crunch 2007-2008." Journal of Economic Perspectives 23 (1): 77-100.

Brunnermeier, Markus, and Martin Oehmke. 2013. “The Maturity Rat Race.” Journal of Finance 68 (2): 483-521.

Campbell, John Y. and Luis M. Viceira. 2002. Strategic Asset Allocation: Portfolio Choice for Long-Term Investors. Oxford University Press, Oxford.

Caprio, Gerard, and Aslı Demirgüç-Kunt. 1998. "The Role of Long-Term Finance: Theory and Evidence.” World Bank Research Observer 13 (2): 171-89.

Chernykh, Lucy, and Alexandra K. Theodossiou. 2011. "Determinants of Bank Long-Term Lending Behavior: Evidence from Russia.” Multinational Finance Journal 15 (3-4): 193216.

Claessens, Stijn, and Sergio Schmukler. 2007. "International Financial Integration through Equity Markets: Which Firms from Which Countries Go Global?” Journal of International Money and Finance 26 (5): 788-813. 
Constant, Fouopi, and Augustin Ngomsi. 2012. "Determinants of Bank Long-Term Lending Behavior in the Central African Economic and Monetary Community." Review of Economics and Finance 2 (2): 107-14.

Corbo, Vittorio, and Klaus Schmidt-Hebbel. 2003. "Macroeconomic Effects of the Pension Reform in Chile.” In Pension Reforms: Results and Challenges. Santiago: International Federation of Pension Fund Administrators.

Cortina-Lorente, Juan Jose, Tatiana Didier Brandao, and Sergio Schmukler. 2016. "How Long Is the Maturity of Corporate Borrowing? Evidence from Bond and Loan Issuances across Markets.” Policy Research Working Paper WPS 7815. World Bank.

Cortina-Lorente, Juan Jose, Tatiana Didier Brandao, and Sergio Schmukler. 2017. "Corporate Debt Maturity in Developing Countries." World Bank.

Davies, Richard, Andrew G. Haldane, Mette Nielsen, and Silvia Pezzini. 2014. "Measuring the Costs of Short-termism.” Journal of Financial Stability, 12, 16-25.

Davis, E. Philip. 1998. Pension Funds: Retirement Income Security and Capital Markets: An International Perspective. Oxford: Oxford University Press.

Davis, E. Philip, and Benn Steil. 2001. Institutional Investors. Cambridge, MA: MIT Press.

De Haas, Ralph, Daniel Ferreira, and Anita Taci. 2010. "What Determines the Composition of Banks' Loan Portfolios? Evidence from Transition Countries." Journal of Banking and Finance 34: 388-98.

de la Torre, Augusto, Juan Carlos Gozzi, and Sergio L. Schmukler. 2017. Innovative Experiences in Fostering Finance: Market Friendly Roles for the Visible Hand? Latin American Development Forum Series. World Bank.

Della Croce, Raffaele, Fiona Stewart, and Juan Yermo. 2011. "Promoting Longer-term Investment by Institutional Investors: Selected Issues and Policies." OECD Journal: Financial Market Trend 2011 (1): 145-64.

Demirgüç -Kunt, Asl1, and Vojislav Maksimovic. 1996. "Stock Market Development and Financing Choices of Firms." World Bank Economic Review 10 (2): 341-69.

Diamond. 1991. "Debt Maturity Structure and Liquidity Risk." Quarterly Journal of Economics 106 (3): 709-37.

Diamond, Douglas, and Philip Dybvig. 1983. "Bank Runs, Deposit Insurance, and Liquidity." Journal of Political Economy 91 (3): 401-19.

Diamond, Douglas, and Raghuram Rajan. 2001. "Liquidity Risk, Liquidity Creation, and Financial Fragility: A Theory of Banking.” Journal of Political Economy 109: 287-327.

Didier, Tatiana, Ross Levine, and Sergio L. Schmukler. 2015. "Capital Market Financing, Firm Growth, and Firm Size Distribution.” Policy Research Working Paper 7353. World Bank.

Djankov, Simeon, Caralee McLiesh, and Andrei Shleifer. 2007. "Private Credit in 129 Countries." Journal of Financial Economics 84 (2): 299-329.

Eichengreen, Barry, and Ricardo Hausmann. 1999. "Exchange Rates and Financial Fragility.” In Federal Reserve Bank of Kansas City Proceedings 329-68.

Fan, Joseph P. H., Sheridan Titman, and Garry Twite. 2012. "An International Comparison of Capital Structure and Debt Maturity Choices." Journal of Financial and Quantitative Analysis 47: 23-56. 
Financial Stability Board, 2013. "Financial Regulatory Factors Affecting the Availability of Long-Term Investment Finance." Report to G20 Finance Ministers and Central Bank Governors, Basel.

Financial Times. 2015. "Big Investors Need to Take More Risk." February 25.

G-20 (Group of 20). 2013. "Long-Term Investment Financing for Growth and Development: Umbrella Paper." Presented to the Meeting of the G20 Ministers of Finance and Central Governors in Moscow

Gelb, Alan, Silvana Tordo, Havard Halland, Noora Arfaa, and Gregory Smith. 2014. "Sovereign Wealth Funds and Long-term Development Finance: Risk and Opportunities." Policy Research Working Paper 6776, World Bank, Washington, DC.

Gelos, Gaston. 2011. "International Mutual Funds, Capital Flow Volatility, and Contagion: A Survey." IMF Working Papers 11/92. International Monetary Fund.

Giovannini, Alberto, Colin Mayer, Stefano Micossi, Carmine di Noia, Marco Onando, Marco Pagano, and Andrea Polo. 2015. "Restarting European Long-term Investment Finance: A Green Paper Discussion Document." Centre for Economic Policy Research, London.

Gozzi, Juan Carlos, Ross Levine, María Soledad Martinez Pería, and Sergio Schmukler, 2015. "How Firms Use Domestic and International Corporate Bond Markets." Journal of Banking and Finance 58: 532-551.

Hart, Oliver, and John Moore. 1995. "Debt and Seniority: An Analysis of Hard Claims in Constraining Management." American Economic Review 85: 567-87.

Impavido, Gregorio, Esperanza Lasagabaster, and Manuel Garcia-Huitron. 2010. "Competition and Asset Allocation Challenges for Mandatory DC Pensions: New Policy Directions." Washington, DC: World Bank.

Impavido, Gregorio, Alberto Musalem, and Thierry Tressel. 2003. "The Impact of Contractual Savings Institutions on Securities Markets." Policy Research Working Paper 2948, World Bank, Washington, DC.

Jeanne, Olivier. 2009. "Debt Maturity and the International Financial Architecture." American Economic Review 99 (5): 2135-48.

Jeanne, Olivier, and Anastasia Guscina. 2006. "Government Debt in Emerging Market Countries: A New Data Set." IMF Working Paper 06/98, International Monetary Fund, Washington, DC.

Kpodar, Kangni, and Kodzo Gbenyo. 2010. "Short- versus Long-Term Credit and Economic Performance: Evidence from the WAEMU.” IMF Working Paper 10/115. International Monetary Fund, Washington, DC.

Love, Inessa, María Soledad Martinez Pería, and Sandeep Singh. 2016. "Collateral Registries for Movable Assets: Does Their Introduction Spur Firms' Access to Bank Finance?” Journal of Financial Services Research. 49(1), 1-37.

Martinez Pería, Maria S., and Sandeep Singh. 2014. "The Impact of Credit Information Sharing Reforms on Firm Financing." Policy Research Working Paper 7013. World Bank.

OECD (Organisation for Economic Co-operation and Development). 2013a. "G20-OECD Highlevel Principles of Long-term Investment Financing by Institutional Investors". Paris: OECD. 
. 2013b. "The Role of Banks, Equity Markets and Institutional Investors in Long-Term Financing for Growth and Development." Report for G20 Leaders, Paris.

. 2013c. "Annual Survey of Large Pension Funds and Public Pension Reserve Funds." Report on Pension Funds' Long-term Investments. OECD, Paris.

. 2014. "Are Institutional Investors the Answer for Long-term Development Financing?"

In Development Co-operation Report 2014: Mobilising Resources for Sustainable Development. Paris: OECD.

Opazo, Luis, Claudio Raddatz, and Sergio Schmukler. 2015. "Institutional Investors and LongTerm Investment: Evidence from Chile.” Word Bank Economic Review.

Qian, Jun, and Philip E. Strahan. 2007. "How Laws and Institutions Shape Financial Contracts: The Case of Bank Loans." Journal of Finance 62 (6): 2803-34.

Raddatz, Claudio. 2010. "When the Rivers Run Dry: Liquidity and the Use of Wholesale Funds in the Transmission of the U.S. Subprime Crisis." Policy Research Working Paper 5203, World Bank, Washington, DC.

Rajan, Raghuram. 1992. 'Insiders and Outsiders: The Choice between Informed and Arm'sLength Debt." Journal of Finance 47 (4): 1367-400.

Rey, Patrick, and Joseph Stiglitz. 1993. "Short-term Contracts as a Monitoring Device.” NBER Working Papers 4514, National Bureau of Economic Research, Cambridge, MA.

Rodrik, Dani, and Andres Velasco. 2000. "Short-term Capital Flows." In Annual World Bank Conference on Development Economics 2000, edited by B. Pleskovic, and J. Stiglitz. Washington, DC: World Bank.

Rudolph, Heinz. 2009. "State Financial Institutions: Mandates, Governance and Beyond.” Policy Research Working Paper 5141, World Bank, Washington, DC.

Rudolph, Heinz P., Richard Hinz, Pablo Antolín, and Juan Yermo, eds. 2010. Evaluating the Financial Performance of Pension Funds. Washington, DC: World Bank.

Scott, David. 2007. "Strengthening the Governance and Performance of State-Owned Financial Institutions." Policy Research Working Paper 4321, World Bank, Washington, DC.

Shin, Hyun Song. 2013. "The Second Phase of Global Liquidity and Its Impact on Emerging Economies." Princeton University, Princeton, NJ.

Stewart, Fiona. 2014. "The Use of Outcome-Based Benchmarks: Proving Incentives for LongTerm Investment by Pension Funds.” Policy Research Working Paper 6885, World Bank, Washington, DC.

Stiglitz, Joseph, and Andrew Weiss. 1981. "Credit Rationing in Markets with Imperfect Information.” American Economic Review 71 (3): 393-410.

Tasic, Nikola, and Neven Valev. 2008. "The Maturity Structure of Bank Credit: Determinants and Effects on Economic Growth.” Andrew Young School of Policy Studies Research Paper Series 08-12, Georgia State University, Atlanta.

The Economist. 2013. "Pension Funds Can and Should Invest More in Infrastructure." October 26.

2014. "How to Get More of the World's Savings to Pay for New Roads, Airports, and Electricity." March 22.

—. 2015a. "Short-term or Short-changed?" May 2. 
- 2015b. "A New Contract for Growth.” August 15.

Tirole, Jean. 2003. "Inefficient Foreign Borrowing: A Dual- and Common-Agency Perspective." American Economic Review 93 (5): 1678-702.

Warnock, Veronica, and Francis Warnock. 2008. "Markets and Housing Finance.” Journal of Housing Economics 17: 239-51.

World Bank. 2015. Long-term Finance. Global Financial Development Report 2015-2016. Washington, DC: World Bank. 
Figure 1. Average Share of Bank Loans in Advanced and Developing Economies by Maturity, 2005-12

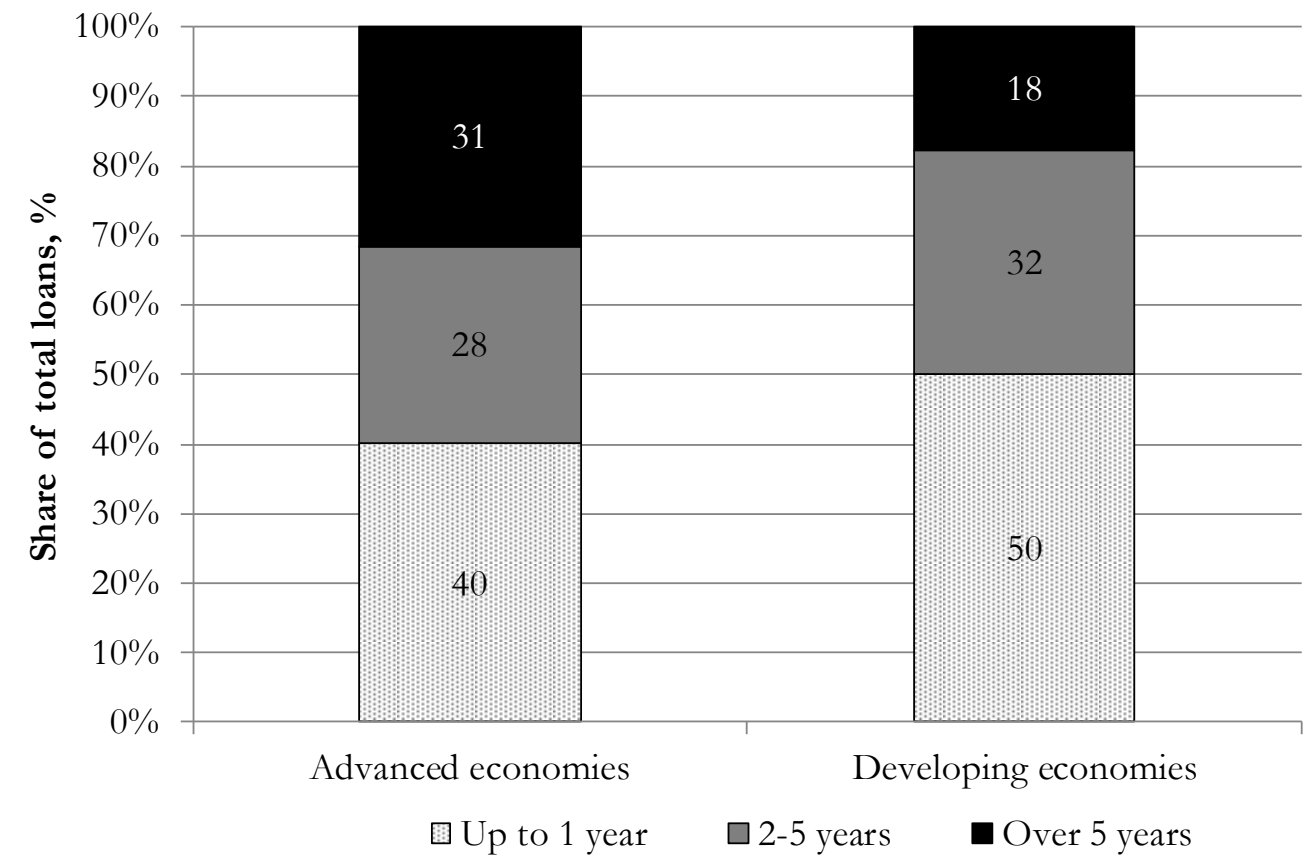

Source: World Bank (2015)

Figure 2. Capital Market Size and Composition by Country Income Group, 2000-11

Upper-middle-income

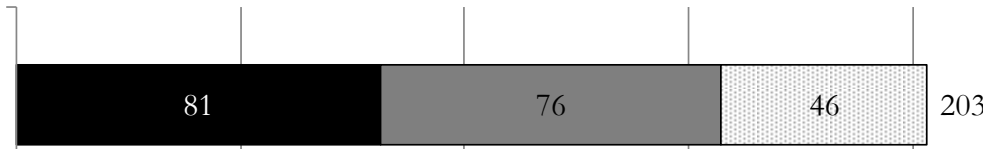

Lower-middle- \& low-income
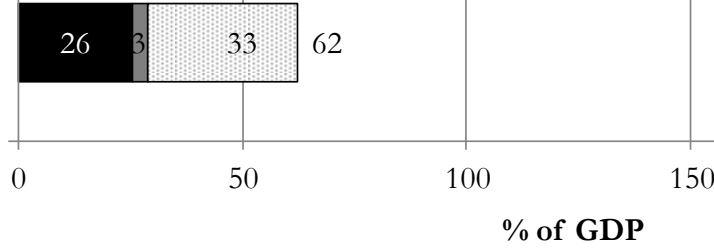

- Stock market capitalization

$\square$ Private debt

a Public debt 

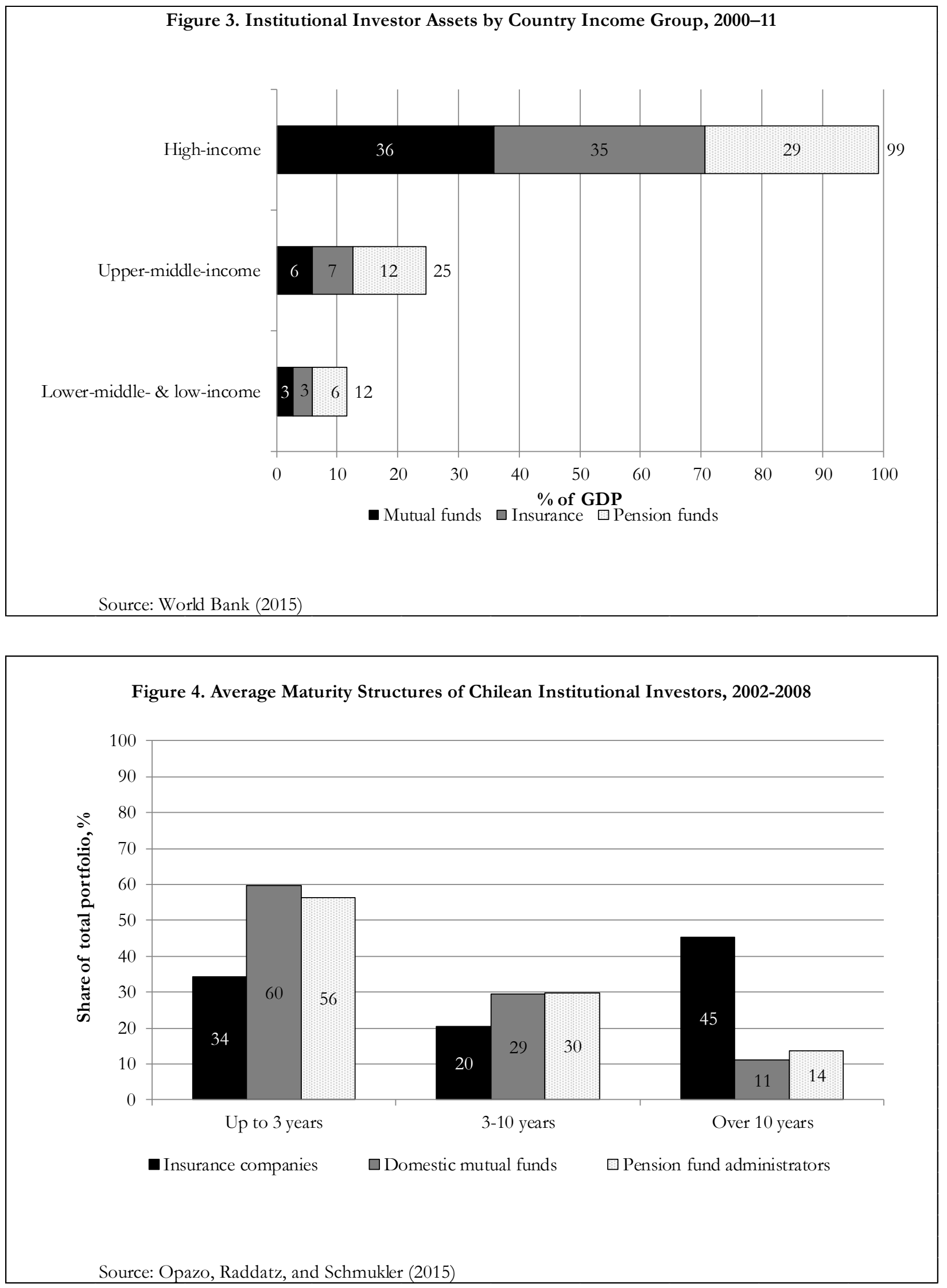
Figure 5. Comparison of Average Maturity of Corporate Bonds

Held by U.S. and U.K. Mutual Funds and Domestic Mutual Funds, 2013

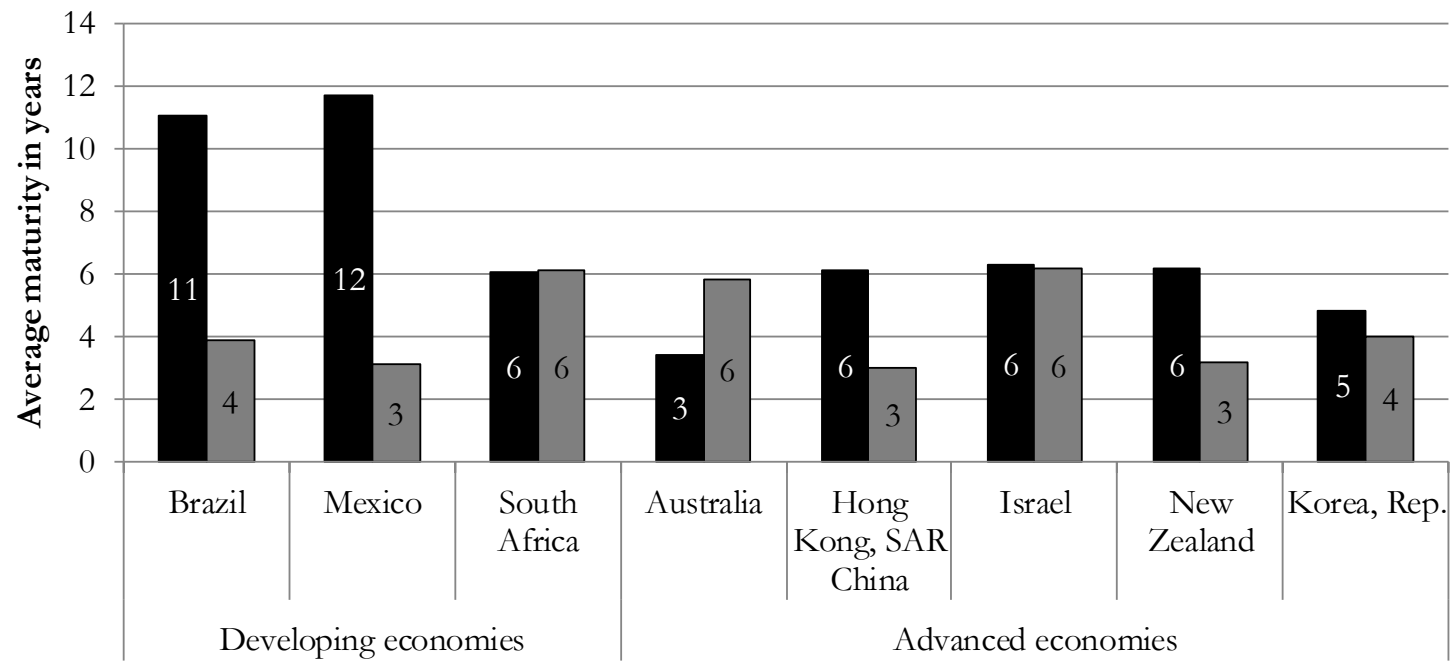

שU.S. and U.K. funds $\square$ Domestic funds 